\title{
Primary Education Teachers' Attitudes Towards and Views on Differentiated Instruction on Geography
}

\author{
Aikaterini Klonari ${ }^{1}$ \& Eleni Koutaleli ${ }^{1, *}$ \\ ${ }^{1}$ Dept. of Geography, University of the Aegean, University Hill, Mytilene, Lesvos, 81100, \\ Greece \\ *Correspondence: Dept. of Geography, University of the Aegean, University Hill, Mytilene, \\ Lesvos, 81100, Greece. Tel: 30-22510-36449. E-mail: koutaleli.e@geo.aegean.gr
}

Received: July 10, 2017 Accepted: August 2, 2017 Published: September 20, 2017

doi:10.5296/ije.v9i3.11893 URL: https://doi.org/10.5296/ije.v9i3.11893

\begin{abstract}
This paper presents the results of a study on Primary Education teachers' attitudes towards and views on the implementation of differentiated instruction on Geography. The research tool was a questionnaire with 16 open and closed questions, which was distributed to a sample of 173 teachers teaching in 45 out of 99 pilot schools throughout Greece in 2014. The results of the research have shown that: a) a large number of teachers state that they are adequately, well and very well familiar with differentiated instruction; b) most teachers believe that students' learning readiness, interests, and learning profile - combined with the use of a series of educational equipment and materials - constitute a very crucial parameter for the proper implementation of differentiated instruction; c) most teachers maintain that research in groups is a very useful teaching strategy for differentiated instruction; and d) a significant number of teachers consider lack and organisation of teaching time as the main obstacle in designing and implementing differentiated instruction on Geography.
\end{abstract}

Keywords: Differentiated Instruction, Geography, Primary Education, New Geography Curricula 


\section{Introduction}

Differentiated instruction is defined as the overall design of learning process through flexible and alternative teaching strategies and practices, which aim to respond to each student's difference in terms of their learning readiness, interests, and learning profile (Tomlinson, 2014).

It is based on the notion of constructivism (Piaget, 1973) and social constructivism (Vygotsky, 1978), and comprises a combination of many theories, educational strategies and practices (Tomlinson, 2014). It is a natural consequence of enhanced understanding we currently have of how children learn in modern classrooms, which are characterised by lack of uniformity in students' potential and are defined as mixed-ability classrooms (Tomlinson \& Mc Tighe, 2006).

In Greece differentiated instruction is highlighted as a necessity with the latest changes and amendments of the Detailed Curricula (DC), the Cross-thematic Curriculum Framework for Compulsory Education (CCFCE) (Pedagogical Institute, 2003), and the New Curricula (NC), whose primary goal was to modernise the content of compulsory education (Pedagogical Institute, 2010; Mandrikas \& Melista, 2011).

Moreover, the New Geography Curricula introduce the use of innovative teaching strategies and practices, such as cooperative learning, association of preexisting knowledge with new information, projects made by students and student groups, integration of technology in learning process, active learning, etc., which are theoretical and operational parameters of differentiated instruction, contributing the most to its effectiveness in the classroom.

With a view to the more effective use of the undergoing innovations, a great number of teachers in Greece were trained, thus getting the necessary time required to implement what they learned (Klonari \& Mandrikas, 2014; Klonari et al, 2014).

Therefore, the aim of our research, the results of which are presented in this paper, is to explore teachers' attitudes towards and views on the implementation of differentiated instruction on Geography in Primary Education.

\section{Theoretical Framework}

\subsection{Modern Geographical Training in Greece}

Modern geographical education in Greece ultimately aims to improve the quality of people's life in their environment, whether natural or human induced. This is the case because there is now awareness of the overarching and multiple contribution of geographical and environmental education to the development and quality of citizens' life, in a globalised environment with great social and economic rearrangements, population movements, environmental threats, changes in climatic conditions of many areas around the world and wars, where often even human rights are restricted (Klonari et al, 2011).

Geographical education in Greece is organised and delivered through the Geography Curriculum, which responds to contemporary trends involving the discipline of Geography, 
Pedagogy and Didactics (Klonari et al, 2014).

The main axis of the Geography Curriculum is that students acquire an adequate body of knowledge, consistent with contemporary needs, which contains cognitive equipment of critical interpretation of the real world, aiming to create and maintain a dynamic and harmonious interaction between space, humanity, and the environment, thus increasing the chances that tomorrow's citizens may have a better quality of life (Klonari \& Mandrikas, 2014; Klonari et al, 2011).

The main medium for achieving the aforementioned axis of the didactics of Geography develops students' spatial thinking and cultivating their spatial skills, as a medium of communication and interaction of tomorrow's citizens (Azevedo et al, 2016; Hespanha et al, 2009; Gersmehl \& Gersmehl, 2007), which involves processing data within spatial frameworks, collecting and recording information with geographical content, decoding maps, illustrating geographical elements and orienting spatially (Klonari \& Mandrikas, 2014).

Moreover, at the level of teaching methodology, a systematic and organised effort is made to change teaching strategies and practices, so that the educational dimension of Geography will escape the sterile memorisation of numbers, names, definitions, as it used to be the case in primary school for many years (Klonari \& Koutsopoulos, 2005; Katsikis, 2002; Klonari, 2002). Therefore, the use of educational equipment is reinforced (Gioti \& Katsikis, 2007; Lambrinos $\&$ Bibou, 2006), and emphasis is placed on utilising experiential, cooperative and discovery learning as innovative approaches to knowledge.

\subsection{New Geography Curricula in Relation to the Implementation of Differentiated Instruction on the Educational Process}

The significance in differentiation of instruction, using the innovations it introduces, particularly in Geography, is presented on the "New Curriculum - Teacher's Guide on the course of Geography”. In Klonari et al. 2011 (p. 9), among the basic principles of teaching methodology of Geography, is: "Utilisation, during teaching, of students' experience, which will determine the forms of teaching differentiation in accordance with the philosophy of the New School".

These innovations - such as the use of New Technologies, team work, gradation of activities, cross-thematic approach to knowledge - operate within a constructive learning context, where each child contributes according to their learning profile, the level of their learning readiness, their interests, and constructs the meaning of what is negotiated during the educational process (Sfyroera, 2007).

For instance, the effectiveness of the use of Information Technology in the didactics of Geography has been demonstrated in a relevant research carried out in Secondary Education by Klonari and Passadelli (2016) on a sample of 21 students of the 1st grade of Lower Secondary School ( $7^{\text {th }}$ grade of compulsory education). The results of the research have shown that almost all students improved their initial cognitive level in a mixed-ability class, thus illustrating that differentiated instruction supported with New Technologies activates both interest and participation of students in the lesson (Klonari \& Passadelli, 2016; Klonari et al, 2015). 
Nevertheless, a necessary parameter of successful implementation of differentiated instruction on Geography in practice is the properly organised and adequate training of teachers in implementing it thereof in the classroom. Based on training, according to Hawkins (2009), teachers will be enabled to enhance their skills and knowledge so to adequately respond to students' learning needs with varied characteristics. For this reason, the initial training of teachers must be constantly maintained, with the corresponding support of competent training agencies and trainers, when teachers begin to implement what they have learned. In addition to the support from the competent agencies and trainers, it is also important that trained teachers will be encouraged to cooperate with one another, exchange of ideas and get feedback.

In Greece, similar training was delivered to the teachers of 99 pilot primary schools as to how implement differentiated instruction on Geography in Primary Education during 2011-2012, with the support of the Ministry of Education. Such training was part of the overall framework of teachers' training in the New Curricula, and, thus, in differentiation of instruction, which, as mentioned above, is one of the main objectives of modern education approach to Geography (Pedagogical Institute, 2010; Mandrikas \& Melista, 2011).

The training results were presented in relevant papers (Klonari \& Mandrikas, 2014; Klonari et al, 2014). Klonari et al (2014) reported that teachers thought that training seminars (in the form of workshops) were very useful, and offered maximum results through experiential learning. Moreover, teachers' majority supported that there is a "universal" correlation between the teaching objectives and the activities proposed by the New Curricula. Finally, it is noteworthy that teachers stated that their students were impressed very positively from their teaching plans, on which their teaching was based, and which contained a series of differentiated educational strategies/practices.

\section{Aim of the Study}

This study is part of a wider study on the effectiveness of learning process, utilising differentiated instruction on Geography, and it addresses 6th-grade Primary Education students. In this paper, we will present the results of a questionnaire distributed to school teachers that implemented (or had to implement) the New Curricula, aiming (a) to explore their attitudes towards and views on differentiated teaching in general and on teaching Geography in particular; and (b) to subsequently specify the teachers who implemented it and the schools where it was implemented and see whether those teachers wanted to become study subjects, so that its effectiveness will be explored.

\subsection{Research Questions}

Based on the aim of the study, the following research questions arise:

- How many teachers state that they know what differentiated instruction is?

- Which parameters are considered by teachers to be important for the proper implementation of differentiated instruction on Geography? 
- What are teachers' attitudes towards and views on the contribution of New Curricula to the course of Geography?

- Which are the teaching strategies/practices that teachers should implement in the subject of Geography?

- Which obstacles are considered by teachers to be the basic ones in designing and implementing differentiated instruction on Geography?

\section{Methodology}

\subsection{Participants}

The subjects of the study were 173 teachers of the $5^{\text {th }}$ and the $6^{\text {th }}$ grade of 45 Pilot Primary Schools in the Greek territory out of the 99 schools that had been initially selected to operate as such. Most were women $(N=100,58.5 \%)$, they were over 46 years old $(N=107,61.9 \%)$, and they were graduates of a Department of Education or a Pedagogical Academy $(N=110,63.6 \%)$. Regarding the years of their service, they had (almost equally) small, medium, and large work experience (Table 1). Also, 45 (26.0\%) of the participating teachers worked in Attica.

Finally, $16(9.6 \%)$ teachers, when asked, stated that they had already received training in differentiated instruction on Geography.

Table 1. Description of the Characteristics of the Teachers' Sample

\begin{tabular}{|c|c|c|}
\hline & $N$ & $\%$ \\
\hline \multicolumn{3}{|l|}{$\operatorname{Sex}(N=171)$} \\
\hline Male & 71 & 41.5 \\
\hline Female & 100 & 58.5 \\
\hline \multicolumn{3}{|l|}{ Age Group } \\
\hline $25-35$ years old & 21 & 12.1 \\
\hline $36-45$ years old & 45 & 26.0 \\
\hline $46-50$ years old & 72 & 41.6 \\
\hline over 51 years old & 35 & 20.3 \\
\hline \multicolumn{3}{|l|}{ Education } \\
\hline Department of Education & 57 & 32.9 \\
\hline Pedagogical Academy, Pedagogical Academy by equalisation & 53 & 30.7 \\
\hline $\begin{array}{l}\text { Department of Education or Pedagogical Academy by equalisation, Second } \\
\text { degree }\end{array}$ & 42 & 24.3 \\
\hline Post-Graduate degree, Ph.D. & 21 & 12.1 \\
\hline \multicolumn{3}{|l|}{ Years of service $(\mathrm{N}=172)$} \\
\hline $1-15$ & 61 & 35.4 \\
\hline $16-25$ & 60 & 34.9 \\
\hline over 26 & 51 & 29.7 \\
\hline \multicolumn{3}{|l|}{ Employment Location } \\
\hline Attica & 45 & 26.0 \\
\hline Outside Attica & 128 & 74.0 \\
\hline \multicolumn{3}{|l|}{ Training in differentiated instruction of Geography $(\mathrm{N}=167)$} \\
\hline Yes & 16 & 9.6 \\
\hline No & 151 & 90.4 \\
\hline
\end{tabular}




\subsection{Tools}

Based on the literature review (Creswell, 2014; Cohen et al, 2011; Iosifidis, 2008; Robson, 2007), a research was conducted by means of a questionnaire, which contained open and closed questions.

The questionnaire consisted of two parts. The first part contained questions regarding the demographic data of the respondents' teachers such as sex, age, etc., and 7 questions (from 1 to 7) of teachers' training in differentiated instruction in general, and in Geography in particular.

The $2^{\text {nd }}$ part consisted of 9 questions (from 8 to 16), which examined teachers' knowledge of, attitudes towards and views on the theoretical and operational framework of differentiated instruction on Geography, as well as on relevant teaching strategies/practices they implement.

\subsection{Procedure}

Special permission from the Ministry of Education was required for the study to be conducted. We, then, contacted the principals of the pilot primary schools. We explained the aim of this research paper in order to get their permission to distribute questionnaires to the teachers of those schools, as was the case either in person or electronically.

From February until June 2014 we received completed questionnaires. During the last term of 2014 we processed the questionnaires, performing a quantitative and qualitative analysis of them.

\subsection{Data Analysis}

Description statistics indices (absolute - percentile frequencies) were used for the presentation of the variables concerned. To explore the relation between the dependent variables (i.e. teachers' knowledge of and attitude towards differentiated instruction) and the independent variables concerned (i.e. sex, age, education, years of service, employment location, training in differentiated instruction on Geography) Pearson chi- square tests for independence $\left(\chi^{2}\right)$ were performed, with the required adjustments thereof (Fisher's exact- Monte Carlo tests). In order to further study a statistically significant relation between the categorical variables, we applied adjusted residual tests. All tests were conducted at the level of statistic significance of .05 , while the analysis was performed by using the statistical software SPSS v22.

\section{Results}

\subsection{Teachers'Statements about Their Knowledge of What Differentiated Instruction Is}

Most participants stated that they had adequate $(N=70,44.6 \%)$, good $(N=25,15.9 \%)$ and very good knowledge $(N=9,5.7 \%)$ of what differentiated instruction is, while $33.8 \%(N=53)$ of them stated that they have no knowledge of what differentiated instruction is. Those statements by the teachers showed significant variety based on their sex $\left(\chi^{2}(3)=3.39, p=.335\right)$, age $\left(\chi^{2}(9)=\right.$ $5.42, p=.805)$, years of service $\left(\chi^{2}(6)=8.17, p=.215\right)$ and employment location $\left(\chi^{2}(3)=0.78\right.$, $p=.855)$. By contrast, statistically significant differences among the teachers were recorded 
based on their education $\left(\chi^{2}(9)=16.49, p=.039\right)$ and on whether they were trained in differentiated instruction on Geography $\left(\chi^{2}(3)=17.28, p<.001\right)$. In more detail, it appeared that the teachers who held a postgraduate degree and/or a Ph.D. stated at a comparatively greater level than what was expected that they know very well what differentiated instruction is (Table 2), and teachers trained in differentiated instruction on Geography recorded higher rates than what was expected in good - very good knowledge thereof, and lower rates than what was expected in ignorance thereof, unlike non-trained teachers (Table 3).

Table 2. Investigation of the Relation between Knowledge of the Content of Differentiated Instruction and the Participants' Education $(N=157)$

\begin{tabular}{|c|c|c|c|c|c|}
\hline \multicolumn{2}{|c|}{$\begin{array}{l}\text { Knowledge of differentiated } \\
\text { instruction }\end{array}$} & \multicolumn{4}{|l|}{ Education } \\
\hline & & $\begin{array}{l}\text { Department } \\
\text { of Education }\end{array}$ & $\begin{array}{l}\text { Pedagogical } \\
\text { Academy, } \\
\text { Pedagogical } \\
\text { Academy by } \\
\text { equalisation }\end{array}$ & $\begin{array}{l}\text { Department of } \\
\text { Education or } \\
\text { Pedagogical } \\
\text { Academy by } \\
\text { equalisation, } \\
\text { Second degree }\end{array}$ & $\begin{array}{l}\text { Post-Graduate } \\
\text { degree, Ph.D. }\end{array}$ \\
\hline \multirow[t]{3}{*}{ None } & $\mathrm{N}$ & 23 & 13 & 14 & 3 \\
\hline & $\%$ & 41.1 & 27.1 & $42.4 \%$ & 15.0 \\
\hline & Adjusted residuals & 1.4 & -1.2 & 1.2 & -1.9 \\
\hline \multirow[t]{3}{*}{ Adequately } & $\mathrm{N}$ & 21 & 26 & 14 & 9 \\
\hline & $\%$ & 37.5 & 54.2 & $42.4 \%$ & 45.0 \\
\hline & Adjusted residuals & -1.3 & 1.6 & -0.3 & 0.0 \\
\hline \multirow[t]{3}{*}{ Well } & $\mathrm{N}$ & 9 & 8 & 5 & 3 \\
\hline & $\%$ & 16.1 & 16.7 & 15.2 & 15.0 \\
\hline & Adjusted residuals & 0.0 & 0.2 & -0.1 & -0.1 \\
\hline \multirow[t]{3}{*}{ Very good } & $\mathrm{N}$ & 3 & 1 & 0 & 5 \\
\hline & $\%$ & 5.4 & 2.1 & 0.0 & 25.0 \\
\hline & Adjusted residuals & -0.2 & -1.3 & -1.6 & 4.0 \\
\hline
\end{tabular}

Table 3. Investigation of the Relation between Knowledge of the Content of Differentiated Instruction and the Participants' Training $(N=152)$ Therein

\begin{tabular}{|c|c|c|c|}
\hline & & \multicolumn{2}{|c|}{ Training in differentiated instruction on Geography } \\
\hline \multicolumn{2}{|c|}{ Knowledge of differentiated instruction } & Yes & No \\
\hline \multirow{3}{*}{$\overline{\text { None }}$} & $\mathrm{N}$ & 1 & 50 \\
\hline & $\%$ & 6.7 & 36.5 \\
\hline & Adjusted residuals & -2.3 & 2.3 \\
\hline \multirow[t]{3}{*}{ Adequately } & $\mathrm{N}$ & 4 & 64 \\
\hline & $\%$ & 26.7 & 46.7 \\
\hline & Adjusted residuals & -1.5 & 1.5 \\
\hline \multirow{3}{*}{ Well } & $\mathrm{N}$ & 7 & 17 \\
\hline & $\%$ & 46.7 & 12.4 \\
\hline & Adjusted residuals & 3.5 & -3.5 \\
\hline \multirow[t]{3}{*}{ Very good } & $\mathrm{N}$ & 3 & 6 \\
\hline & $\%$ & 20.0 & 4.4 \\
\hline & Adjusted residuals & 2.4 & -2.4 \\
\hline
\end{tabular}


5.2 The Significant Parameters Involving Proper Design, Application, And Assessment of Differentiated Instruction

As far as the parameters of successful differentiated instruction are concerned, $28(45.2 \%)$ teachers reported that the emphasis that must be placed on students' learning readiness, their interests and learning profile, through the use of a series of educational equipment and materials, $13(21.0 \%)$ teachers emphasized the teacher's flexibility in projects, educational process during teaching, and assessment, $11(17.7 \%)$ teachers mentioned the creation and maintenance of mixed-ability groups, six $(9.7 \%)$ teachers reported the positive classroom ambiance, two (3.2\%) teachers reported the association of prior experience with the new one, while two $(3.2 \%)$ teachers gave an unclear answer. The designation of these parameters did not vary significantly on the basis of the participants' age $\left(\chi^{2}(15)=15.32, p=.318\right)$, education $\left(\chi^{2}(15)=18.64, p=.107\right)$, years of service $\left(\chi^{2}(10)=4.78, p=.969\right)$, employment location $\left(\chi^{2}(5)=\right.$ $4.65, p=.403)$ and training in differentiated instruction on Geography $\left(\chi^{2}(5)=2.74, p=.750\right)$. By contrast, statistically significant differences among teachers were recorded based on their $\operatorname{sex}\left(\chi^{2}(5)=13.03, p=.012\right)$, as women stressed, to a comparatively greater extent, the creation and maintenance of mixed-ability groups, and men stressed, to a greater extent, teachers' flexibility in projects, education process during teaching and in assessment (Table 4).

Table 4. Investigation of the Relation between the Designation of the Parameters Involving Successful Differentiated Instruction and the Participants' Sex $(N=62)$

\begin{tabular}{|c|c|c|c|}
\hline & & \multicolumn{2}{|l|}{$\underline{\operatorname{Sex}}$} \\
\hline \multicolumn{2}{|c|}{ Parameters of successful differentiated instruction } & Male & Female \\
\hline Emphasis on students' interests, the learning & $\mathrm{N}$ & 14 & 14 \\
\hline \multicolumn{2}{|l|}{ profile, and learning readiness, using a variety of $\%$} & 48.3 & $42.4 \%$ \\
\hline educational equipment and materials & Adjusted residuals & 0.5 & -0.5 \\
\hline \multirow[t]{3}{*}{ Positive classroom ambiance } & $\mathrm{N}$ & 3 & 3 \\
\hline & $\%$ & 10.3 & 9.1 \\
\hline & Adjusted residuals & 0.2 & -0.2 \\
\hline \multirow{3}{*}{$\begin{array}{l}\text { Emphasis on prior experience and knowledge, } \\
\text { and association with the new one }\end{array}$} & $\mathrm{N}$ & 1 & 1 \\
\hline & $\%$ & 3.4 & 3.0 \\
\hline & Adjusted residuals & 0.1 & -0.1 \\
\hline \multirow{3}{*}{$\begin{array}{l}\text { Mixed-level groups carrying out cooperative } \\
\text { projects }\end{array}$} & $\mathrm{N}$ & 1 & 10 \\
\hline & $\%$ & 3.4 & 30.3 \\
\hline & Adjusted residuals & -2.8 & 2.8 \\
\hline \multirow{3}{*}{$\begin{array}{l}\text { Flexibility in designing, implementing and } \\
\text { assessing the educational process }\end{array}$} & $\mathrm{N}$ & 10 & 3 \\
\hline & $\%$ & 34.5 & 9.1 \\
\hline & Adjusted residuals & 2.5 & -2.5 \\
\hline \multirow[t]{3}{*}{ Unclear } & $\mathrm{N}$ & 0 & 2 \\
\hline & $\%$ & 0.0 & 6.1 \\
\hline & Adjusted residuals & -1.3 & 1.3 \\
\hline
\end{tabular}




\subsection{The Contribution of the New Curricula to Differentiated Instruction of Geography}

As regards New Curricula of Geography, 62.3\% $(N=86)$ of the participants gave a positive answer regarding their contribution to instruction differentiation in Geography, while $37.7 \%$ $(N=52)$ gave a negative answer. On the one hand, this attitude was not affected in a statistically significant manner by the participants' $\operatorname{sex}\left(\chi^{2}(1)=0.22, p=.639\right)$, age $\left(\chi^{2}(3)=4.55, p=.208\right)$, years of service $\left(\chi^{2}(2)=1.97, p=.373\right)$, employment location $\left(\chi^{2}(1)=2.16, p=.142\right)$ and training in differentiated instruction on Geography $\left(\chi^{2}(1)=0.19, p=.662\right)$. On the other hand, a statistically significant difference among teachers was recorded on the basis of their education $\left(\chi^{2}(3)=16.26, p=.001\right)$, where the graduates of the Pedagogical Academy and Pedagogical Academy by equalisation defended the significance of New Curricula more than the other ones, unlike those who held a postgraduate degree and/or a Ph.D., who challenged it more (Table 5).

In particular, as regards the manner of contribution of the New Geography Curricula, $42.2 \%$ $(N=30)$ of the teachers who replied $(N=71)$ seemed to particularly appreciate their contribution to the educational work, because the differentiated instruction that underpins the framework allows teachers to have flexibility in teaching and in the educational equipment. $31.0 \%(N=22)$ of the teachers assessed them positively, as they promote students' group cooperation, and $11.3 \%(N=8)$ of them assessed them positively with regard to the learning object, because there is knowledge-building, while $15.5 \%(N=11)$ of the teachers gave an unclear or tautological reply.

Table 5. Investigation of the Relation between the Designation of the Contribution of New Geography Curricula to the Differentiation of Instruction on Geography and the Participants' Education $(N=138)$

\begin{tabular}{|c|c|c|c|c|c|}
\hline \multirow{2}{*}{\multicolumn{2}{|c|}{$\begin{array}{l}\text { Contribution of the New } \\
\text { Geography Curricula }\end{array}$}} & \multicolumn{4}{|l|}{ Education } \\
\hline & & $\begin{array}{l}\text { Department of } \\
\text { Education }\end{array}$ & $\begin{array}{l}\text { Pedagogical } \\
\text { Academy, } \\
\text { Pedagogical } \\
\text { Academy by } \\
\text { equalisation }\end{array}$ & $\begin{array}{ll}\begin{array}{l}\text { Department } \\
\text { Education } \\
\text { Pedagogical }\end{array} \\
\text { or } \\
\text { Academy } \\
\text { equalisation, by } \\
\text { Second degree }\end{array}$ & $\begin{array}{l}\text { Post-Graduate } \\
\text { degree, Ph.D. }\end{array}$ \\
\hline Yes & $\mathrm{N}$ & 28 & 36 & 15 & 7 \\
\hline \multirow{3}{*}{ No } & $\begin{array}{l}\% \\
\text { Adjusted residuals }\end{array}$ & $\begin{array}{l}58.3 \\
-0.7\end{array}$ & $\begin{array}{l}85.7 \\
3.8\end{array}$ & $\begin{array}{l}50.0 \\
-1.6\end{array}$ & $\begin{array}{l}38.9 \\
-2.2\end{array}$ \\
\hline & $\mathrm{N}$ & 20 & 6 & 15 & 11 \\
\hline & $\begin{array}{l}\% \\
\text { Adjusted residuals }\end{array}$ & $\begin{array}{l}41.7 \\
0.7\end{array}$ & $\begin{array}{l}14.3 \\
-3.8\end{array}$ & $\begin{array}{l}50.0 \\
1.6\end{array}$ & $\begin{array}{l}61.1 \\
2.2 \\
\end{array}$ \\
\hline
\end{tabular}

\subsection{The Teaching Strategies/Practices That Teachers Implement in the Subject of Geography}

As far as the teaching strategy/practice they would use during the application of differentiated instruction on Geography is concerned, the participants $(N=74)$ reported research groups $(N=$ $33,44.6 \%)$, graded activities $(N=9,12.2 \%)$, learning centres $(N=5,6.8 \%)$, a series of other 
educational practices $(31.0 \%)$, while four $(5.4 \%)$ unclear practices were also recorded. No statistically significant differences were detected in teachers' report based on their $\operatorname{sex}\left(\chi^{2}(4)=\right.$ $6.09, p=.179)$, age $\left(\chi^{2}(12)=11.36, p=.415\right)$, education $\left(\chi^{2}(12)=9.22, p=.652\right)$, years of service $\left(\chi^{2}(8)=11.49, p=.123\right)$, employment location $\left(\chi^{2}(4)=0.93, p=.953\right)$ and training in differentiated instruction on Geography $\left(\chi^{2}(4)=1.58, p=.863\right)$.

\subsection{Most Basic Obstacles That Teachers Encounter While Designing and Implementing Differentiated Instruction on Geography}

To detect what kind of difficulties teachers face while designing and implementing differentiated instruction on Geography, the difficulties teachers deal with were divided into those they face while designing and those they face while implementing differentiated instruction on Geography. Thus, the main difficulties the teachers $(N=51)$ encounter while designing involved the time they needed to design a lesson with differentiated instruction $(N=$ $27,52.9 \%)$, plan and organise the lesson $(N=18,35.3 \%)$, logistical infrastructures, and educational material $(N=5,9.8 \%)$, while one $(2.0 \%)$ participant did not give a clear answer. On the one hand, the report of such difficulties faced by the participants was not significantly affected by their $\operatorname{sex}\left(\chi^{2}(3)=3.69, p=.261\right)$, age $\left(\chi^{2}(9)=10.15, p=.353\right)$, education $\left(\chi^{2}(9)=9.98\right.$, $p=.286)$, years of service $\left(\chi^{2}(6)=9.18, p=.089\right)$ and training in differentiated instruction on Geography $\left(\chi^{2}(3)=4.96, p=.151\right)$. On the other hand, there was a statistically significant difference among teachers based on their employment location $\left(\chi^{2}(3)=7.12, p=.039\right)$, which is traced in the fact that logistical infrastructures and educational material were designated as a basic difficulty to a greater extent by those who worked in Attica (Table 6).

Table 6. Investigation of the relation of the designation of the difficulties in the design of differentiated instruction on Geography and the participants' employment location $(N=51)$

\begin{tabular}{llll}
\hline & & \multicolumn{2}{l}{ Employment Location } \\
\cline { 2 - 4 } Difficulties in designing differentiated & Anstruction on Geography & Attica & Outside Attica \\
\hline The time & $\mathrm{N}$ & 6 & 21 \\
& $\%$ & 60.0 & 51.2 \\
& Adjusted residuals & 0.5 & -0.5 \\
The logistical infrastructures and the & $\mathrm{N}$ & 3 & 2 \\
educational material & $\%$ & 30.0 & 4.9 \\
& Adjusted residuals & 2.4 & -2.4 \\
Scheduling for designing the lesson & $\mathrm{N}$ & 1 & 17 \\
& $\%$ & 10.0 & 41.5 \\
& Adjusted residuals & -1.9 & 1.9 \\
Unclear & $\mathrm{N}$ & 0 & 1 \\
& $\%$ & 0.0 & 2.4 \\
& Adjusted residuals & -0.5 & 0.5 \\
\hline
\end{tabular}


Similarly, the difficulties more often encountered by the participants who had implemented differentiated instruction on Geography $(N=53)$ involved teaching time $(N=23,43.4 \%)$, lack of education on the part of the students in implementing differentiated instruction in the classroom $(N=19,35.8 \%)$, and the available logistical infrastructures and educational material $(N=8,15.1 \%)$, while three teachers $(5.7 \%)$ gave an unclear-non relevant answer or gave a tautological answer. No statistically significant differences were detected in those answers given by teachers on the basis of their $\operatorname{sex}\left(\chi^{2}(4)=2.25, p=.838\right)$, age $\left(\chi^{2}(12)=12.60, p=.395\right)$, education $\left(\chi^{2}(12)=10.16, p=.617\right)$, years of service $\left(\chi^{2}(8)=12.19, p=.066\right)$, employment location $\left(\chi^{2}(4)=4.14, p=.401\right)$ and training in differentiated instruction on Geography $\left(\chi^{2}(4)=\right.$ $3.25, p=.553)$.

\section{Conclusions - Discussion}

\subsection{Knowledge and Training of Teachers on What Differentiated Instruction of Geography Is}

The results of the study show that a significant number of teachers stated that they are adequately, well and very well familiar with what differentiated instruction is.

What is noteworthy is that among the teachers who stated that they were familiar with differentiated instruction were not only teachers who had already received training, a result which was to be expected, but also several teachers who had received no training.

This seeming contradiction, on the one hand, between a small number of teachers stating that they have received adequate training in differentiated instruction, and, on the other hand, a larger number of teachers stating that they are adequately familiar with it, is probably due to the fact that teachers may have not received systematic training in differentiated instruction, yet feel adequate when it comes to implement it while teaching. Besides, according to Borrero and Bird (2009), teachers always used to implement elements of differentiation in their teaching, long before it gained popularity.

Moreover, knowledge of differentiated instruction was largely stated by teachers holding a postgraduate and doctoral degree.

The above research conclusion appears to be consistent with the fact that, within the context of the discipline of contemporary Pedagogy, in sectors of which teachers are trained and specialised with postgraduate and doctoral studies, it is to be expected that they have engaged in a series of modern and innovative teaching strategies/practices, such as the use of New Technologies, cross-thematic integration, the project method, work in groups, which constitute basic parameters of instruction differentiation.

\subsection{The Most Important Parameters on Implementing Differentiated Instruction on Geography}

Teachers' answers that emphasise students' learning profile, learning readiness, and interests, while using a series of educational materials and equipment, such as maps, computers, etc., as a basis and starting point of designing, implementing and assessing differentiated instruction, were expected, because exactly those parameters constitute the essence of differentiated 
instruction, and are the main axis of the philosophy of constructivism. In other words, the creation of an environment where students will build up meaning through different cognitive pathways, by selecting a series of media, materials, and strategies (Tomlinson \& Imbeau, 2010; Tomlinson, 2014). Moreover, this is consistent with the New Geography Curricula, which support the necessity of using varied educational equipment and materials, and emphasise student-centered and teamwork models of teaching, as opposed to the use of traditional methods (Klonari et al., 2014; Apostolopoulou \& Klonari, 2013; Gioti \& Katsikis, 2007; Lambrinos \& Bibou, 2006). In particular, teaching with the aid of Information Technology, as a significant educational equipment that offers many options of alternative presentation of themes in the classroom, other than sticking to the knowledge offered by the handbook, allows to implement differentiated instruction, encourages participation, attracts students' attention, and guarantees the effectiveness of learning, as it was demonstrated in relevant studies (Klonari \& Passadelli, 2016; Klonari et al, 2015).

There is a difference between female and male teachers in that female teachers place importance on creating and maintaining mixed-ability groups, while male teachers place greater importance on teachers' flexibility in projects, while teaching, it may be because female teachers appear to have greater interpersonal skills than their male counterparts, which is supported by the relevant study by Krips et al. (2011).

These interpersonal skills are analysed in a series of actions, such as paying attention to students' feelings, encouraging students verbally and non-verbally, when they try to answer, verbally underlining the children's efforts and successes to the rest of the group (Krips et al, 2011).

In combination with the above research, as it is demonstrated in the relevant literature and papers, women in principle place importance on feelings through social interaction in order to negotiate situations, while men focus more on where they think there is a practical and unexpected problem to solve (Shehzad \& Nasir, 2013; Krips et al, 2011; Alnabhan, 2008).

This conclusion may justify, on the one hand, the importance female teachers place on creating mixed groups, which are in principle beneficial to all students, primarily to the ones facing learning difficulties, as they become part of a team, and are assisted by the others. On the other hand, male teachers, consistent with the stereotypes that regard them more practical, appear to place greater importance on the cognitive process of teaching, which is designing more effective projects for the duration of educational process, and students' assessment thereafter.

\subsection{The Contribution of the New Detailed Curricula to Differentiated Instruction on Geography}

The results of our research demonstrate that teachers largely agree with the contribution of New Geography Curricula to differentiated instruction, thus justifying the philosophy of the New Geography Curricula, which support and stress the necessity of instruction differentiation in educational process.

The aforementioned findings also agree with the research by Klonari \& Mandrikas (2014), which showed that teachers who had received training in differentiated teaching 
strategies/practices considered the New Geography Curricula quite useful and effective within the operational educational context.

Moreover, teachers who recognise the importance of the contribution of the New Geography Curricula within the context of differentiated instruction primarily recognise it as their own axis and are encouraged to flexible use the means and materials they are supplied with; they are also encouraged to use specific proposals and a series of teaching actions for each teaching unit, where such proposals are provided in the "New Curriculum - Teacher's Guide for the course of Geography" (Klonari et al, 2011).

The results also showed that teachers holding a postgraduate or doctoral degree challenged the importance of the New Geography Curricula more than the other teachers. The above finding may be because teachers who had developed their studies further possibly had some additional ideas about teaching strategies/practices that could be implemented in a classroom, and, thus, greater expectations from the New Geography Curricula as regards their contribution to differentiated instruction in a classroom.

\subsection{The Teaching Strategies/Practices That Teachers Implement in the Subject of Geography}

Teachers believe that group work is a very useful teaching strategy. The above finding appears to be consistent with the view on the New Geography Curricula, where emphasis is placed on flexibility of instruction, employing experiential, cooperative exploration and discovery learning as innovative approaches to knowledge (Pedagogical Institute, 2003).

Students' collaboration is included in the axis concerning the differentiation of the Curriculum, because it is considered to be the primary factor that enhances the positive ambiance in the classroom.

Besides, one of the main duties of teachers is to create a learning environment where conditions favour positive interaction between participants in the learning process, so that each of them will maximise their learning (Tomlinson, 2000).

The operational dimension of the creation of a positive learning environment by the teacher initially includes deep knowledge of students' personality, their learning needs, respect for their difference, and then design and implementation of flexible grouping, graded activities, flexibility in assessing and adapting to the detailed curriculum (Gregory \& Chapman, 2013).

\subsection{The Most Basic Obstacles in Designing and Implementing Differentiated Instruction on Geography}

The teachers questioned maintained, as their answers showed, that a basic obstacle in designing and implementing differentiated instruction is time. Those results agree with relevant international studies, which also indicate the difficulty that teachers encounter in using the teaching time (Wan, 2017; Acosta-Tello \& Shepherd, 2014; Tobin \& Tippett, 2014; Lewis \& Batts, 2005)

It is worth to being noted that in the present study teachers did not list their lack of training as an obstacle, unlike a series of studies where teachers list their lack of training as a main 
reason that creates obstacles for them in implementing differentiated instruction both in general and in new pedagogical and teaching approaches to their work (De Jager, 2016; Wiggins \& Mc Tighe, 2013; Teriot \& Tice, 2008), while the results of the study by Klonari and Mandrikas (2014) indicated the usefulness of such training both for teachers and for students.

It should also be noted that there is a statistically significant difference in terms of the obstacles and difficulties in designing a differentiated subject, which arose among teachers because of their employment location.

The difference is detected in the fact that logistical infrastructures and the educational equipment were listed as a basic difficulty factor in designing a differentiated Geography lesson by teachers working outside Attica comparatively more than teachers working within Attica. This finding appears to be consistent with the study of Vergidis (2008), where it is indicated that in many regional areas of Greece, teachers encounter difficulties in their teaching, due to the lack of logistical infrastructures. It is also demonstrated that this problem has existed for many years in the Greek educational reality, as in a relevant paper by Tzani (1983), where she reports that schools in remote areas and areas outside the capital show lack of logistical infrastructure.

In general, although relevant studies show that differentiated instruction works positively for students' performance and teachers' attitudes and views (Gray, 2008; Mastropieri et al, 2006; Lo, 2006; Baumgather et al, 2003; Tieso, 2001; Lynch \& Warner, 2008), there is no broad and widespread practical implementation thereof. A series of studies show that, although most teachers understand the importance of instruction differentiation, in teaching practice they are not willing to differentiate their teaching so as to adjust it to children's academic differences (Westberg \& Daoust, 2003; Guild, 2001; Gable et al, 2000).

\section{Study Limitations}

Those findings give us an image of Primary Education teachers' attitudes towards and views on the implementation of differentiated instruction on Geography. Nevertheless, there is a limitation to the study, as not all of school teachers answered, but only $50 \%$ of those who were sent the questionnaire, and, therefore, we cannot generalise our conclusions. Therefore, further research should be conducted with a larger sample of teachers questioned.

\section{References}

Acosta-Tello, E., \& Shepherd, C. (2014). Equal access for all learners: Differentiation simplified. Journal of Research in Innovative Teaching, 7, 51-57.

Alnabhan, M. (2008). Assessing the high school teachers' emotional intelligence in Karak district of Jordan. Gifted and Talented International, 23(1), 81-86. http://dx.doi.org/10.1080/15332276.2008.11673514 
Apostolopoulou, Aik., \& Klonari, Aik. (2013). Interpretation of the natural relief through the use of maps by Primary School students. In Vavougios, D. and Paraskevopoulos, St. (Ed) Proceedings of the $8^{\text {th }}$ Pan-Hellenic Conference on Teaching Science and New Technologies in Education, 914-921. Volos: University of Thessaly. (in greek).

Azevedo, L., Ribeiro, V., \& Osório, A. (2016). Promoting a Spatial Perspective on Primary Students Through Geotechnologies. Proceedings of EDULEARN16 Conference, 6455-6459. 4th-6th July 2016, Barcelona, Spain: IATED.

Baumgartner, T., Lipowski, M. B., \& Rush, C. (2003). Increasing reading achievement of primary and middle school students through differentiated instruction (Master Thesis). Available online from Education Resources Information Center (ERIC No. ED479203). Retrieved November 11, 2016 from https://eric.ed.gov/?id=ED479203

Borrero, N., \& Bird, S. (2009). Closing the achievement gap: How to pinpoint student strengths to differentiate instruction and help your striving readers succeed. NY: Scholastic. http://dx.doi.org/10.14507/er.v0.1182

Cohen, L., Manion, L., \& Morrison, K. (2011). Research Methods in Education (7th ed.). New York: Routledge.

Creswell, J. W. (2014). Educational Research: Planning, Conducting, and Evaluating Quantitative and Qualitative Research (5 ${ }^{\text {th }}$ Ed.). London, UK: Pearson.

De Jager, T. (2016). Perspectives of teachers on differentiated teaching in multi- cultural South African secondary schools. Studies in Educational Evaluation. Retrieved August 25, 2016 from http://dx.doi.org/10.1016/j.stueduc.2016.08.004

Gable, R. A., Hendrickson, J. M., Tonelson, S. W., \& Van Acker, R. A. (2000). Changing disciplinary and instructional practices in the middle school to address IDEA. Clearing House, 73(4), 205-208. http://dx.doi.org/10.1080/00098650009600951

Gersmehl, P.J., \& Gersmehl, C.A. (2008). Spatial Thinking by Young Children: Neurologic Evidence for Early Development and "Educability". Journal of Geography, 106(5), 181-191. http://dx.doi.org/10.1080/00221340701809108

Gioti, K., \& Katsikis, A. (2007). Educational equipment in the course of Geography Comparative viewing. In Katsikis, A., Kotsis, K, Mikropoulos, A. \& G. Tsaparlis (Eds) Proceedings of the $5^{\text {th }}$ Pan-Hellenic Conference Pan-Hellenic Conference on Teaching Science and New Technologies in Education, 5(B), 840-848. Ioannina: University of Ioannina. Retrieved from http://www.enephet.gr/index.php?page=proceedings-conference\&proceeding_conferenc e_id $=6$

Gray, J. (2008). The implementation of differentiated instruction for learning disabled student included in general education elementary classroom (Doctoral dissertation). La Verne, California: University of Laverne. UMI Number: 3351121

Gregory, G.H., \& Chapman, C. (2013). Differentiated instructional strategies: One size does 
not fit all. Thousand Oaks, CA: Corwin.

Guild, P.B. (2001). Diversity, learning style and culture. New Horizons for Learning. Retrieved August 25, 2016 from http://www.newhorizons.org/strategies/styles.guild.htm

Hawkins, V. J. (2009). Barriers to implementing differentiation: Lack of confidence, efficacy and perseverance. The NERA Journal, 44(2), 11-16.

Hespanha, S.R., Goodchild, F., \& Janelle, D.G. (2009). Spatial Thinking and Technologies in the Undergraduate Social Science Classroom. Journal of Geography in Higher Education, 33(1), S17-S27. http://dx.doi.org/10.1080/03098260903033998

Iosifidis, Th. (2008). Qualitative research methods in social sciences. Athens: Kritiki (in greek)

Katsikis, A. (2002). The New Geography Curriculum of Primary Education - A critical review. Science Education-Research and Praxis, 2, 32-36. (in greek).

Klonari, A., \& Koutsopoulos, K. (2005). Primary and secondary educators' attitudes on school geography. In K. Donert \& P. Charzynski (Ed.), Changing horizons in geography education, 151-155. Torun, Poland: Herodot Network.

Klonari, A., \& Mandrikas, A. (2014). Experiential in-service teachers' training for the pilot of the new Geography curriculum in Greece: A different experience with tangible results [online]. Review of International Geographical Education Online (RIGEO), 4(2), 138-154.

Klonari, A., Mandrikas, M., Karabatsa, A., Chalkidis, A., Melista, A., \& Tzoura, M. (2015). The New Geography Curriculum for Primary School - Secondary School, and Proposed Educational Material. In Skoubourdi, Ch. \& Skoumios M. (Ed.), Proceedings of the 1st Pan-Hellenic Conference with International Participation on the Educational Material in Mathematics and Science Education. Rhodes, 17-18 October 2015, 161-172.

Klonari, A., \& Passadelli A.S. (2015). The Implementation of ICT in Teaching and Students' Learning of Geohazards in Secondary Education. Teaching Science: Research and Praxis, $54-55,8-24$.

Klonari, Aik. (2002). The status of Geography in compulsory Education in Greek schools today. Proceedings of the 6th Pan-Hellenic Geographical Conference, V. A, 529-534: 3-6 October, Thessaloniki: Hellenic Geographical Society.

Klonari, Aik., Dalaka, A., \& Petanidou, Th. (2011). How evident is the apparent? Students' and teachers' perception of the terraced landscape. IRGEE, 20(1), 5-20. http://dx.doi.org/10.1080/10382046.2011.540100

Klonari, Aik., Mandrikas, A., Melista, A., \& Tzoura, M. (2014). One year pilot implementation of the new Greek geography curriculum in primary education [online]. European Journal of Geography, 5(1), 81-97.

Krips, H., Lehtsaar, T., \& Kukemelk, H. (2011). About the Differences of Teachers' 
Self-perceptions to the Statements of Social Competence [online]. US-China Education Review, B1, 139-149.

Lambrinos, N., \& Bibou, I. (2006). Learning Geography with a "Geography Box" [Online]. International Research in Geographical and Environmental Education, 15(3), 241-254. http://dx.doi.org/10.2167/irgee195.0

Lewis, S. G., \& Batts, K. (2005). How to implement differentiated instruction? Adjust, adjust, adjust: North Carolina Project Begins with Encouragement from Administrators. Journal of Staff Development, 26(4), 26-31.

Lo, L. (2006). Barriers and facilitators to differentiation of English instruction in Taiwan elementary schools (Doctoral dissertation). University of Southern California. UMI Number: 3238323. Retrieved August 25, 2016 from https://search.proquest.com/docview/305281235

Lynch, S.A., \& Warner, L. (2008). Creating Lesson Plans for all Learners. Kappa Delta Pi Record, 45(1), 10-15. http://dx.doi.org/10.1080/00228958.2008.10516525

Mandrikas, A., \& Melista, A. (2011). New Geography Curriculum for Primary Education: Teacher Guide. Retrieved August 25, 2016 from

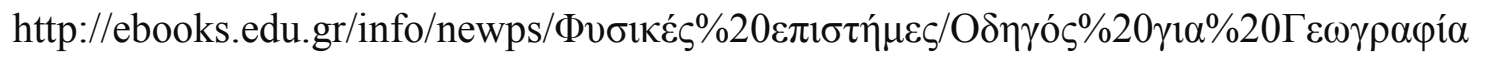
$\% 20 \Delta \eta \mu о \tau$ $к о$.pdf

Mastropieri, M.A., Scruggs, T.E., Berkeley, S., McDuffie, K., Tornquist, E.H., \& Connors, N. (2006). Differentiated curriculum enhancement in inclusive middle school science: Effects on classroom and high stake tests. The Journal of Special Education, 40(3), 130-137.

Pedagogical Institute (2003). Geology-Geography Curriculum for Primary School. Government Gazette, Series II, No 304/13-03-03, volume B, 4200-4213.

Pedagogical Institute (2010). The new School: Student First, p. 17. (in greek). Retrieved August 25, 2016 from http://1 dim-aei-thess.thess.sch.gr/neo\%20sxoleio.pdf

Piaget, J. (1973). To Understand is To Invent: the future of education. New York: Grossman.

Robson, C. (2007). Investigation of the actual world. Translated by Vasilikou K., Dalakou V. Athens: Gutenberg. (in greek).

Sfyroera, M. (2007). Differentiated Education (2 Ed). Athens, University of Athens: On Demand S.A. Retrieved August 6, 2016 from http://reader.ekt.gr/bookReader/show/index.php?lib=EDULLL\&item=903\&bitstream=9 03_01\#page/2/mode/2up (in greek).

Shehzad, S., \& Nasir, M., (2013). Gender Differences in Emotional Intelligence of University Teachers. Pakistan Journal of Social and Clinical Psychology, 11(1), 16-21.

Theriot, S., \& Tice, K. (2009). Teachers' knowledge development and change: Untangling beliefs and practices. Literacy Research \& Instruction, 48, 65-75. 
http://dx.doi.org/10.1080/19388070802226287

Tieso, C. (2001). Curriculum: Broad brushstrokes or paint-by-the numbers? Teacher Educator, 36, 199-213. http://dx.doi.org/10.1080/08878730109555264

Tobin, R., \& Tippett, C.D. (2014). Possibilities and Potential Barriers: Learning to Plan for Differentiated Instruction in Elementary Science. International Journal of Science and Mathematics Education, 12(2), 423-443.

Tomlinson, C. A. (2000). Reconcilable differences: Standards - based teaching and differentiation. Educational Leadership, 58, 6-11.

Tomlinson, C. A., \& Imbeau, M.B. (2010). Leading and Managing a Differentiated Classroom. Alexandria, VA: Association for Supervision and Curriculum Development.

Tomlinson, C. A., \& McTighe, J. (2006). Integrating Differentiated Instruction \& Understanding by Design: Connecting Content and Kids. Alexandria, VA: Association for Supervision and Curriculum Development.

Tomlinson, C.A. (2014). The Differentiated Classroom: Responding to the Needs of All Learners $\left(2^{\text {nd }}\right.$ Ed.). Alexandria, VA: Association for Supervision and Curriculum Development.

Tzani, M. (1983). School success: Issue of class and culture origin. Athens: Grigoris. (in greek).

Vergidis, D. (2012). Teachers' training in Greece as a dimension of the educational policy. Science and Society: Journal of Political and Moral Theory, 29, 97-126.

Vygotsky, L. (1978). Interaction Between Learning and Development. In Gauvain \& Cole (Eds) \& Reading on the Development of Children. New York: Scientific American Books pp. 34-40.

Wan, W.Y. S. (2017). Differentiated instruction: are Hong Kong in-service teachers ready?. Teachers and Teaching Theory and Practice, 23(3), 284-311. http://dx.doi.org/10.1080/13540602.2016.1204289

Wiggins, G., \& McTighe, J. (2006). Examining the Teaching Life. Educational Leadership, 63(6), 26-29.

\section{Copyright Disclaimer}

Copyright for this article is retained by the author(s), with first publication rights granted to the journal.

This is an open-access article distributed under the terms and conditions of the Creative Commons Attribution license (http://creativecommons.org/licenses/by/3.0/). 